\title{
Local Externalities and Ownership Choices in Foreign Acquisitions by Multinational Enterprises
}

\begin{abstract}
This article assesses the influence of spatial hetero-geneity on the entry mode by multinational enter-prises (MNEs) in foreign markets. Focusing on acquisitions, we claim that the location of the target firm influences the MNE's ownership choice. MNEs normally execute partial acquisitions to reduce their liability of foreignness and to preserve their target's inherent competencies, particularly in highly innovative and internationally competitive sectors. However, this phenomenon occurs less frequently if target firms are located in areas that are characterized by relevant externalities, such as core cities and industrial districts. In particular, core cities allow foreign MNEs to access a variety of information and knowledge as well as other externalities that are asso-ciated with international interconnectedness; industrial districts provide MNEs with easier access to industry-specific agglomeration economies (a local pool of skilled labor, local input-output linkages, and local knowledge spillovers). These locations provide substitutes for different aspects of the target firm's competences, thus reducing an MNE's need to main-tain a local partner. Empirical evidence from foreign acquisitions of local manufacturing firms that occurred in Italy during the 2001-10 period confirms these expectations.
\end{abstract}

\footnotetext{
Key words:

local externalities agglomeration economies ownership choice foreign acquisitions multinational enterprises
}

\author{
Sergio Mariotti \\ DIG-Politecnico di Milano Piazza Leonardo da Vinci, \\ 32-20133 Milan, Italy \\ sergio.mariotti@polimi.it \\ Lucia Piscitello \\ DIG-Politecnico di Milano Piazza Leonardo da Vinci, \\ 32-20133 Milan, Italy \\ lucia.piscitello@polimi.it
}

\section{Stefano Elia}

DIG-Politecnico di Milano Piazza Leonardo da Vinci, 32-20133 Milan, Italy stefano.elia@polimi.it 
I iterature in economic geography has emphasized the role of spatial heterogeneity in attracting multinational enterprises (MNEs) (McCann and Mudambi 2005). In fact, the local environment may be a source of information and knowledge spillovers that strongly impact the location and agglomeration processes of MNEs (Alcácer and Chung 2007; Mariotti, Piscitello, and Elia 2010). In principle, the same rationale could be applied to any interplay between an MNE and its territory (Dicken and Malmberg 2001). However, while current knowledge on MNEs' behavior mainly concerns the "why" and "where" they locate across and within different countries (Iammarino and McCann 2013), the evidence about "how" MNEs enter different locations is still scant. In particular, studies on the entry mode choice are almost exclusively conducted at the country level rather than the subnational level ${ }^{1}$ (Beugelsdijk and Mudambi 2013).

Within this context, the present article seeks to investigate the influence of both characteristics of the local environment and relevant externalities on cross-country acquisitions, which are the greatest share of global foreign direct investment (FDI) flows, especially in developed economies (United Nations Conference on Trade and Development 2011). In particular, we model the MNE choice to either maintain a local partner or conduct a complete acquisition of the target firm, by integrating literature on the MNE entry modes with economic geography literature on local externalities and agglomeration economies.

Research in economics and business has suggested that acquisitions are increasingly used as a way to access complementary resources and acquire information and knowledge that may otherwise be difficult to obtain (Meyer, Wright, and Pruthi 2009). This phenomenon is particularly prevalent in sectors that are more likely to provide the acquirer with greater opportunities to learn (i.e., sectors characterized by high knowledge intensiveness and/or a relevant international competitive advantage). Accordingly, MNEs often prefer to engage in partial acquisitions instead of full acquisitions not only to preserve and absorb the distinctive competences of the foreign target firm but also to reduce the uncertainty and risks stemming from the MNE's liability of foreignness (Zaheer 1995). Indeed, local firms can provide general information and knowledge on the characteristics of the local context (North 1990; Tse, Pan, and Au 1997) as well as business-specific information and knowledge with respect to both their distinctive competences and their business networks and relationships (Phene, Tallman, and Almeida 2012). However, we claim that this scenario is likely to change if the charac-teristics of the local environment are appropriately considered. If the context of an acquisition presents local externalities that allow a foreign acquirer to easily and freely access general and/or business-specific information and knowledge, then a foreign MNE's need to maintain a local partner should decrease. In fact, these types of exter-nalities should allow foreign MNEs to reduce their uncertainty and risk and minimize their liability of foreignness. In particular, industrial districts (IDs), which are charac-terized by an industrial atmosphere that includes collective information and knowledge that is specific to the business (Becattini 1991), may allow the MNE to benefit from agglomeration economies that relate to collective learning, labor market pooling, and local buzz. Similarly, core cities (CCs) enjoy urban economies and facilitate the circu-lation of information and the movement of capital, labor, and a variety of other tangible and intangible resources (Duranton and Puga 2004). Moreover, these cities offer access to infrastructural hubs, highly educated employees, and institutional networks, and thus the cities facilitate agglomeration and the fruition of knowledge externalities (Glaeser et al. 1992).

1 Lorenzen and Mankhe (2004) constitute a noteworthy exception. 
To provide evidence for our framework, we analyze foreign acquisitions of local manufacturing firms that occurred in Italy during the 2001-10 period. In particular, we investigate the role of different local externalities in influencing the ownership choices of the MNEs that engaged in these acquisitions by considering the nature/characteristics of the geographic contexts of the relevant target firms. The results from our econometric analysis confirm that MNEs that acquire firms that are located in CCs or IDs are less likely to maintain their local partners, even controlling for industry- and firm-specific heterogeneity.

The remainder of this article is organized as follows. The next section provides our conceptual background and testable hypotheses. The third section presents the data and descriptive statistics of this study, and the econometric models and variables that are employed in this investigation are described in the fourth section. The fifth section illustrates and discusses the results of the econometric analysis, and the final section summarizes the main contributions and limitations of the article.

\section{Conceptual Background \\ The Ownership Choice in Acquisitions by MNEs}

The extant literature has suggested several arguments to explain an MNE's decision to either fully take over a local target firm or maintain its local partner. According to the resource-based view (RBV) of the firm (e.g., Barney 1991), the full acquisition of a local target firm allows foreign investors to acquire and access complex and organizationally embedded knowledge (Barkema and Vermeulen 1998). Similarly, transaction cost economics (TCE) (Williamson 1985) suggests that a higher level of control is needed to reduce the transaction costs that are involved in cross-border acquisitions (Madhok 1997). Thus, full acquisitions allow foreign entrants complete access to, and ownership and control of, the resources of a local firm (Meyer et al. 2009). However, various theoretical explanations have recently been proposed to justify the fact that MNEs frequently opt for partial acquisitions instead of full acquisitions (for a survey, see Chari and Chang 2009). In this study, we rely on the increasingly convergent stream of literature that has been inspired by the RBV and new property rights theory of the firm. According with this approach (Kim and Mahoney 2010), the firm is regarded as a bundle of resources and capabilities that is held together by a nexus of incomplete contracts leading to a rather precarious equilibrium between ownerentrepreneurs and other shareholders, who enjoy residual claimant status, and managers and other key employees, who make highly firm-specific investments (Rajan and Zingales 1998). A takeover could break up this original corporate equilibrium and produce ruinous effects from the acquirer's perspective, with a substantial portion of the distinctive core competences embodied in the target firm that may be dispersed or even destroyed.

This disruptive process is more likely to occur during full acquisitions than during partial acquisitions because the former entail more radical changes. In full acquisitions, key managers and employees often perceive an atmosphere of long-term instability and therefore choose to either retain their existing competences and underinvest in new competences or abandon the firm. A vast body of literature (e.g., Berg 2001; Cannella and Hambrick 1993) has confirmed that turnover rates in acquired top management teams are significantly higher than normal turnover rates and that the exit of managers after an acquisition involves the loss of not only critical knowledge assets but also links and relationships to relevant business and social networks, this way lowering the performance of the target firm. 
This (unintentional) disruption of value in the target firm is likely to be amplified if the acquirer is a foreign MNE (Krug and Hegarty 1997). The integration of a target firm into an international network of subsidiaries increases an MNE's costs of coordination and contributes to the complexities surrounding the management and control of units that are located in foreign markets with distinct cultures, institutions, and competitive environments (Bartlett and Ghoshal 1989). To overcome these difficulties, foreign acquirers often impose their systems and practices on their target firms with little regard for the negative consequences of their actions on the preexisting corporate equilibria (Jemison and Sitkin 1986).

Along this line of reasoning, an MNE seeking to access new complementary resources may prefer to adopt relatively subtle ownership modes that avoid the loss of the target firm's managers, key employees, and social networks, and favor the postentry learning process with respect to the target firm's business and its country-specific information and knowledge (Dyer, Kale, and Singh 2004). In particular, co-ownerships may limit knowledge disruptions, by creating incentives for the seller to transfer information and knowledge to the acquirer (Chen and Hennart 2004), and thanks to less radical corporate changes and less invasive integration processes (Haspeslagh and Jemison 1991).

This conceptual framework may complement approaches in economic geography on the role of spatial heterogeneity (i.e., the characteristics of the locations in which the target firms are located) in influencing foreign acquisitions. In particular, we claim that an MNE's need to maintain a local partner decreases if the local context of the target firm may (at least) partially substitute for the information, knowledge, and relational capital that are embedded in the target firm. Indeed, as the TCE and the RVB have suggested, under conditions of generous local spillovers/agglomeration economies, the full control of target firms allows MNEs to reduce their transaction costs and avoid both organizational complexities and difficulties in acquiring access to shared resources.

\section{The Role of Spatial Heterogeneity}

Local environment may present externalities, the nature and extent of which influence MNEs' acquisition behavior and their ownership decisions. In particular, we focus on externalities that benefit firms that are located in IDs or CCs.

Literature in economic geography conceptualizes the ID as a privileged place for the accumulation of social capital that results from the multiple interactions among economic agents that belong to a local community with shared values and institutions (Lorenzen 2007). This accumulation process gives rise to advantages of firm co-location that can be expressed in terms of the trinity of agglomeration economies, as originally suggested by Marshall (1920): a local pool of skilled labor, local input-output linkages, and local spillovers.

By integrating this theoretical perspective with the RBV, the competences of a firm that is located within an ID can be decomposed into three interrelated and mutually reinforcing components (Camisón 2004): (1) personal competences, that is, the skills that are possessed by an individual or group of individuals within the organization, which may be potentially migratory and largely tacit in nature; (2) corporate competences, which are combinations of knowledge and skills that are embedded in the procedures and organizational routines of the firm; ${ }^{2}$ and (3) shared competences, which include the

\footnotetext{
${ }^{2}$ Corporate competences tend to permeate an organization in a manner that is largely independent from the individual and therefore remain within an organization after individuals or particular groups leave the organization in question (Levitt and March 1988).
} 
assets of knowledge, information, and learning that are deposited in the district and may be regarded as an external space with resources and capabilities that the firm and other members of the district can freely access.

The combination of the three aforementioned components determines the competitive advantages of firms within an ID. In particular, the notion of shared competences stresses the fundamental difference between districtual and nondistrictual firms. For nondistrictual firms, the external knowledge base is territorially dispersed; thus, managers and skilled employees have the pivotal role of using their relational-specific investments to create and maintain necessary ties and linkages to other economic agents and institutions. The noncontractability and inseparability of these human investments from the identities of insiders imply that a firm must strategically retain key employees not only to access their personal competences but also to maintain and further develop the firm's societal and network embeddedness and absorptive capacity. In contrast, districtual firms as part of a business community that shares localized competences, and the organizational routines and procedures of these firms are deeply rooted in local social networks (Crewe 1996; Harrison 1991). The role of individuals as catalysts for embedded social networks is not particularly important because the mobility of people who share experiences, capabilities, and linkages is higher in the district than in the general economy, and because a flexible labor market exists to provide substitutes for insider employees (Power and Lundmark 2004). Instead of destroying bridging ties and linkages, labor flows within the district provide a major method of locally creating a knowledge base and diffusing competences among firms in the business community of interest. ${ }^{3}$

A full acquisition of a firm endangers the different types of competences to different degrees. Based on our conceptual framework, a full acquisition will involve a high risk of losing key personal and corporate competences. However, the risk of losing shared competences will be definitely lower for districtual firms, as the acquirer can maintain and further develop preexisting networks and relationships with institutions. That allows the acquirer to absorb the freely circulating externalities that can be regarded as an essential source of the target firm's competitive advantages. ${ }^{4}$ Additionally, in an acquisition that targets a firm within an ID, sufficient resources exist to compensate for the loss of personal competences in the target firm; in particular, the acquiring firm can take advantage of the intradistrict mobility of individuals and can locally poach managers, technicians, and skilled workers from the ID by offering lucrative salaries and favorable labor conditions (Combes and Duranton 2006; Lipsey and Sjöholm 2005). In other words, we claim that the quantity and quality of competences getting lost in a full acquisition are higher for nondistrictual target firms, because they rely only on personal and corporate competences and because external substitutes for these competences are rare or nonexistent. Thus, the acquirer may engage in a partial acquisition when it has a higher interest in preserving and absorbing the target firm-specific competences. In contrast, in an ID, shared competences and other local externalities provide advantages that function both as complements and as substitutes for other firm-specific competences. Hence, for acquisitions involving districtual firms, a full ownership can be an effective

\footnotetext{
${ }^{3}$ Mobile skilled workers are fundamental to the diffusion of knowledge across firms and within cities or regions. However, mobility of certain individuals (such as technologists and inventors) is bounded in space (Breschi and Lissoni 2009). Thus, organizations must be located within industrial clusters to benefit from the knowledge that is possessed by these individuals and embedded in their network ties (Eriksson 2011).

${ }^{4}$ Evidence from Italian districts confirms that the strategy by MNEs that acquire districtual firms is to become deeply immersed in the industrial atmosphere of the district, to capture novelties and market changes, and to absorb the contextual knowledge that is produced locally (e.g., Belussi and Asheim, 2010; Biggiero, 2002).
} 
strategy to optimize the trade-off between ensuring complete access to, and control of, the target firm-specific assets and risking the loss of a portion of the personal and corporate competences of the target firm, which can be counterbalanced by the opportunity to access the district's competences and resources.

According to economic geography studies, metropolitan cities host the bulk of foreign MNEs (Goerzen, Asmussen, and Nielsen 2013; McCann and Acs 2011). Moreover, the primary loci of merger and acquisition activities are dense urban areas (Rodríguez-Pose and Zademach 2003), that is, a selected group of CCs that are the nodes of the worldwide city network in which specialized knowledge regarding abilities and possibilities in the local market intersect with global flows of information and ideas (Drennan 1992; Short et al. 2000; Taylor 2004).

The emergence of CCs relies not only on urban agglomeration economies that are based on sharing, matching, and learning mechanisms with respect to knowledge, labor, and goods (Duranton and Puga 2004) but also on global interconnectivity and local concentrations of economic and political decision-making power (Rodríguez-Pose and Zademach 2006). These economies are important generators of variety in the form of cross-industry spillovers, recombinant innovations, diversified labor markets, and the intermobility of personnel, thus, offering genuine and fungible externalities to firms in a wide range of sectors (Sassen 2009). CCs offer access to infrastructural hubs, highly educated employees, and institutional networks, and these cities can, and do, play a critical role in the creation of information externalities by allowing for tremendous movements of capital, labor, and other tangible and intangible resources (Glaeser et al. 1992). Moreover, CCs benefit from local buzz (Storper and Venables 2006), that is, the interactive information and communication ecology that is created by face-to-face contacts and by the co-presence and co-location of people, diversified firms, services, government entities, and international agencies. Unsurprisingly, the most globalized cities also feature the greatest quantities of localized buzz because the highest levels of international business interactions by MNEs require a combination of close and distant interactions to function efficiently; that is, these MNEs must insert themselves into locally centered business and government networks and must also obtain access to global pipelines (Bathelt, Malmberg, and Maskell 2004; Moodysson 2008; Trippl, Todtling, and Lengauer 2009).

In this context, MNE subsidiaries that are located in CCs are important points for the accumulation of knowledge and general information regarding the host country's economy and its institutional environment; information circulates in the internal network of MNEs and it is partly transmitted through business relationships between MNEs and other international investors. These MNE subsidiaries become a fundamental part of the $\mathrm{CC}$, virtuously nurturing the local knowledge base and attracting new investments by both foreign and domestic firms. A related consequence is that the subsidiaries of MNEs that are located in CCs benefit from productivity advantages compared to MNE subsidiaries that are located in more peripheral areas of a host country (Melo, Graham, and Noland 2009).

According with our conceptual framework, the spatial externalities that MNEs benefit from if they are located in a CC reduce their need to completely preserve the information and competencies that are embedded in the human resources, routines, and business networks of the target firm. Furthermore, the readily accessible nature of CCs facilitates frequent exchanges of personnel and managerial control among organizations; thus, full acquisitions may be selected more frequently by MNEs in CCs than in more peripheral regions.

Locations in both IDs and CCs reduce an MNE's need to maintain a local partner in a host country. However, an ID primarily provides access to industry-specific knowledge 
and skills; accordingly, the effect of an ID on the MNE's choice of acquisition options is restricted to acquisitions of firms that operate within the cluster of activities in which the district in question is specialized. In contrast, a $\mathrm{CC}$ provides access to not only general information about a nation's business and institutional environment but also more diversified and cross-fertilizing competences, which produce pervasive effects across various sectors. Thus, our hypotheses may be stated as follows:

Hypothesis 1: The likelihood that an MNE will engage in a partial acquisition instead of a full acquisition will decrease if the target firm is located in an ID that is specialized in the same industry as the target firm.

Hypothesis 2: The likelihood that an MNE will engage in a partial acquisition instead of a full acquisition will decrease if the target firm is located in a CC.

\section{The Role of Industry and Firm Heterogeneity}

According to the economics and business literature, firms' choices between full or partial cross-border acquisitions to access knowledge and complementary resources are dependent on the types of economic activity, strategies, and structures of the firms that are involved (for a survey, see Brouthers and Hennart 2007).

First, industries clearly differ with respect to knowledge intensity. Acquisitions in R\&D-intensive industries typically involve target firms that are more likely to possess proprietary technologies and to offer learning opportunities to the acquirer (Chen and Hennart 2004). However, the transfer of know-how to the new owner requires full cooperation from the seller; in accordance with our previous reasoning, leaving the seller with a stake in the firm helps to ensure a smooth and complete knowledge transfer.

The same argument applies not only to other types of knowledge-intensive assets, such as specialized human assets, intangible market assets, innovative organizational techniques and routines, and similar factors (Yin and Shanley 2008), but also to industries in which the host country internationally excels, so that the acquisition of local firms is likely to provide valuable complementary competences to an MNE (Mariotti et al. 2010). Therefore, we expect that an MNE will be more likely to engage in the partial acquisition rather than full acquisition of a local target firm in knowledge-intensive and/or internationally renowned industries than in other industries.

Second, MNE choices regarding ownership can vary over the course of the industry life cycle. ${ }^{5}$ Building on the literature relating the phases of the industry life cycle with propensities for mergers and acquisitions (Klepper 1997; Maksimovic and Phillips 2008) and alliances (Cainarca, Colombo, and Mariotti 1992), we claim that ownership choices in foreign acquisitions depend on the phase of the relevant industry. In particular, the introduction stage is characterized by market, technology, and production uncertainty, and the extent and trajectories of changes are unpredictable. These characteristics will make partial acquisitions more desirable because they are less expensive and easier to reverse than full acquisitions (Yin and Shanley 2008). During the growth stage, technology and markets stabilize, innovation declines, the entry and exit of new firms slows, and

\footnotetext{
5 The industry life cycle theory has been extensively applied to explain changes in innovation and industrial structure and dynamics (for a recent survey, see Pentoniemi 2011). Within the economic geography literature, the phases of the industry life cycle have been correlated with regional development (Markusen 1985), variations in agglomeration externalities (Boschma and Frenken 2011; Neffke et al. 2011; Potter and Watts 2011), and the territorial clustering of firms (Audretsch and Feldman, 1996; Dalum, Pedersen, and Villumsen 2005).
} 
a shakeout of producers eventually occurs. Thus, firms seek to internalize their competitive advantages and extend the monopolistic rents that are associated with exclusive proprietary assets, whereas requirements for flexibility become less stringent. Acquisitions increase in most industries (Klepper 1997), and full ownership typically prevails over partial ownership because the proprietary control of assets becomes crucial to ensure that the greatest possible preservation of appropriability and technological rents will occur. In the maturity phase, opportunities for learning from acquisitions decline, although efforts by industry incumbents to diversify product and market and to "scrape the barrel" for their monopolistic rents could revitalize the propensity toward acquisitions to a certain extent. Finally, the decline phase is marked by the exhaustion of the technological and market potential of an industry and brings the life cycle of the industry to a close. Write-offs and the selling of firms are frequent, and takeovers that seek to access new competencies and assets are more likely to occur outside the sector of interest. In this phase, partnerships can be used only to rationalize operations, create defensive collusions, or realize soft divestments. In summary, we expect that there will be the greatest likelihood of the partial acquisition instead of the full acquisition of a target firm during the introductory phase for an industry; this likelihood should decrease in the growth phase and in subsequent industry phases, which feature reduced opportunities for postentry learning.

Finally, the literature has also emphasized the role of firm-specific characteristics and strategies in the entry and ownership choices of MNEs in foreign countries. In particular, the previous international experience, national culture, and strategic orientation of the parent company (Nielsen and Nielsen 2011), and the size of the local target firm (Hennart and Reddy 1997), have been considered to be among the main characteristics that impact an MNE's chance to reduce its uncertainty and liability of foreignness (Chari and Chang 2009). Previous experience in the host country is likely to facilitate an MNE's search for a partner with suitable complementary resources and to improve the MNE's capabilities to manage its co-ownerships with local partners. ${ }^{6}$ With respect to an MNE's country of origin, the literature on emerging countries reveals that MNEs from these nations severely suffer from not only their poor business-specific competences (Ramamurti 2009) but also a severe liability of foreignness and liabilities that relate to their country of origin (Ramachandran and Pant 2010). Thus, these MNEs tend to expand abroad mainly through partnerships and joint ventures (Wells 1983) because these entry modes enable them to leverage foreign firms' resources and learn from their capabilities (Mathews 2006).

The literature has also suggested several concordant hypotheses about the relationship between an acquirer's propensity to participate in a partial acquisition and the size of the target firm. In particular, the financing constraint hypothesis predicts that acquirers may prefer to engage in minority acquisitions instead of full acquisitions if the target firm is large (Whited 2006). Furthermore, because larger target firms involve more irreversible investments, a partial acquisition may help to reduce the costs and risks of exiting an acquisition and/or allow an acquiring firm to quickly react to market changes (Balakrishnan and Koza 1993; Tse et al. 1997). Under conditions that include

\footnotetext{
${ }^{6}$ It is worth observing that the literature is not unanimous on the positive role of an MNE's previous experience. In fact, the prior accumulation of country-specific information and knowledge may render local partnership less necessary (Meyer, Wright, and Pruthi 2009). Furthermore, MNEs that have accumulated experience in previous local acquisitions may have learned and developed specific organizational routines for integrating acquired local firms, thus causing full acquisition to be a more attractive option for these MNEs (Lopéz-Duarte and García-Canal 2004).
} 
indivisibilities and economies of scale, partial acquisitions can be associated with either a strategy of small losses (Sitkin 1992) or a gradual approach in which a partial stake provides the acquirer with a platform to scale up its commitment to the market by completing a full acquisition of the target at an appropriate time (Folta 1998).

Our expectations are in accordance with the predictions of previous studies. In particular, we conjecture that compared to acquisitions in general, acquisitions that involve either experienced MNEs or MNEs from emerging countries or larger target firms are more likely to be partial.

\section{Data and Descriptive Statistics The Sample}

Our sample encompasses all of the 868 acquisitions by foreign MNEs that occurred in Italy in 90 manufacturing industries (in particular, industries 151 to 372 in the Nace Rev. 1 classification of economic activities) between 2001 and 2010. The data on foreign acquisitions are obtained from the Reprint database, ${ }^{7}$ which is compiled by the Politecnico di Milano and sponsored by the Italian National Institute for Foreign Trade. The 868 examined acquisitions include 548 (63 percent) full acquisitions and 320 (37 percent) partial acquisitions.

\section{The Geographic Dimension}

To identify IDs and CCs, we relied on a database that was constructed by the Italian Office for National Statistics (ISTAT); this database decomposed the Italian territory into 686 Local Labor Areas (LLAs). The definition of LLA is consistent with both standard definitions of urban areas, and the notion of "functional region," which corresponds to "a territorial unit resulting from the organization of social and economic relations in that its boundaries do not reflect geographical particularities or historical events" (Organization for Economic Cooperation and Development 2002, 11). LLAs are aggregations of neighboring municipalities based on daily commuting flows from residences to workplaces, in such a way as to be largely self-contained: within a given LLA, both the share of residents who work locally and the share of employees who reside locally must be at least 75 percent (ISTAT 2006). ${ }^{8}$

Using this classification, subsets of LLAs that indicate IDs and CCs in Italy can be singled out.

We adopted the official classification system for IDs that was proposed by ISTAT based on its Cluster Mapping Project (ISTAT 2006). This project selected appropriate indicators to proxy the intrinsic nature of these districts: the degree of industrialization, the presence of small and medium enterprises, and the degree of production specialization (for details, see Appendix 1). In total, 156 LLAs were identified as IDs.

The IDs were also classified by ISTAT into eight different macroindustries based on each ID's specialization (henceforth "specialized industries"). Table 1 reveals that most of these IDs belong to industries in which Italy has built an international competitive advantage during recent decades (De Benedictis 2005). In terms of employment, the largest cluster of IDs is that associated with metal products, machinery, and equipment;

\footnotetext{
${ }^{7}$ Since 1986, the Reprint database has provided a census of the Italian affiliates of foreign firms. This database is updated annually (for details, see Mariotti and Mutinelli, 2012).

8 The standards for determining Italian LLAs roughly follow the criteria that are used to define Metropolitan Statistical Areas in the United States, Travel to Work Areas in the United Kingdom, Metropolitan Areas and Employment Areas in France, and Urban Employment Areas in Japan.
} 
Table I

Distribution of the Industrial Districts by Industrial Specialization

\begin{tabular}{lcrrr} 
& & \multicolumn{2}{c}{ No. Employees (Manufacturing Industries) } \\
\cline { 3 - 5 } Industrial Specialization & No. Districts & Specialized Industries & Other Industries & Total \\
\hline Textiles and apparel & 45 & 204,340 & 333,095 & 537,435 \\
Metal products, machinery, and equipment & 38 & 334,380 & 252,940 & 587,320 \\
Housing products & 32 & 53,123 & 329,209 & 382,332 \\
Leather and footwear & 20 & 84,754 & 101,926 & 186,680 \\
Food and beverages & 7 & 9,318 & 23,986 & 33,304 \\
Luxury and leisure & 6 & 33,482 & 83,468 & 116,950 \\
Paper and publishing & 4 & 7,663 & 28,333 & 35,996 \\
Chemicals, rubber, and plastics & 4 & 10,515 & 38,070 & 48,585 \\
TOTAL & 156 & 737,575 & $1,191,027$ & $1,928,602$ \\
\hline ' Wood products, furnishing, glass, tiles, ceramic goods, and other nonmetal products. & & \\
2 Jewelry, musical instruments, sporting goods, and toys. & & & \\
Source: Our elaboration of results from ISTAT (2006). & & &
\end{tabular}

the next largest clusters are found in the textiles and apparel industry and leather and footwear industry. Notably, each ID also hosts a large number of manufacturing firms and employees in industries that do not pertain to the district's specialization (henceforth "other industries"). According to our conceptual framework, the effects of a target firm's location within an ID on an MNE's acquisition strategy should greatly differ for these two categories of industries.

To define CCs, we selected the leading Italian cities participating in the world city network, building upon the approach and database of Taylor (2004) (for details, see Appendix 2). By combining indicators of both international connectivity and the local presence of MNEs, we identified four cities and eight relevant LLAs as CCs: Milan (in particular, the five LLAs surrounding the city), Turin (one LLA), Bologna (one LLA), and Rome (one LLA).

Figure 1 illustrates the localization of IDs and CCs in Italy. Notably, both IDs and $\mathrm{CCs}$ are equally spread across the northwest, northeast, and central regions of Italy, whereas southern Italy and the Italian islands are underrepresented. Table 2 also indicates that the overall share of total manufacturing employees who work in the IDs and $\mathrm{CCs}$ is equal to 55 percent; this share ranges from 11 percent in the south regions and islands to 76 percent in the northwest regions. Most importantly, if only the employees who work within the specialized industries of each ID are considered, then this share decreases to an overall average of 31 percent, ranging from 4 percent in the south regions and islands to 40 percent in the northwest regions. Although IDs and CCs must clearly be regarded as key areas of the country, the above data imply that these regions do not encompass all of the most developed portions of Italy. Instead, particularly in the north and central regions of the country, other LLAs host a number of internationally competitive and knowledge-intensive firms that constitute tempting targets for foreign MNEs.

\section{The Geographic Distribution of Acquisitions}

Table 3 presents the distribution of the 868 acquisitions of our sample across the different geographic/industrial categories, that is, the specialized industries of IDs, other 


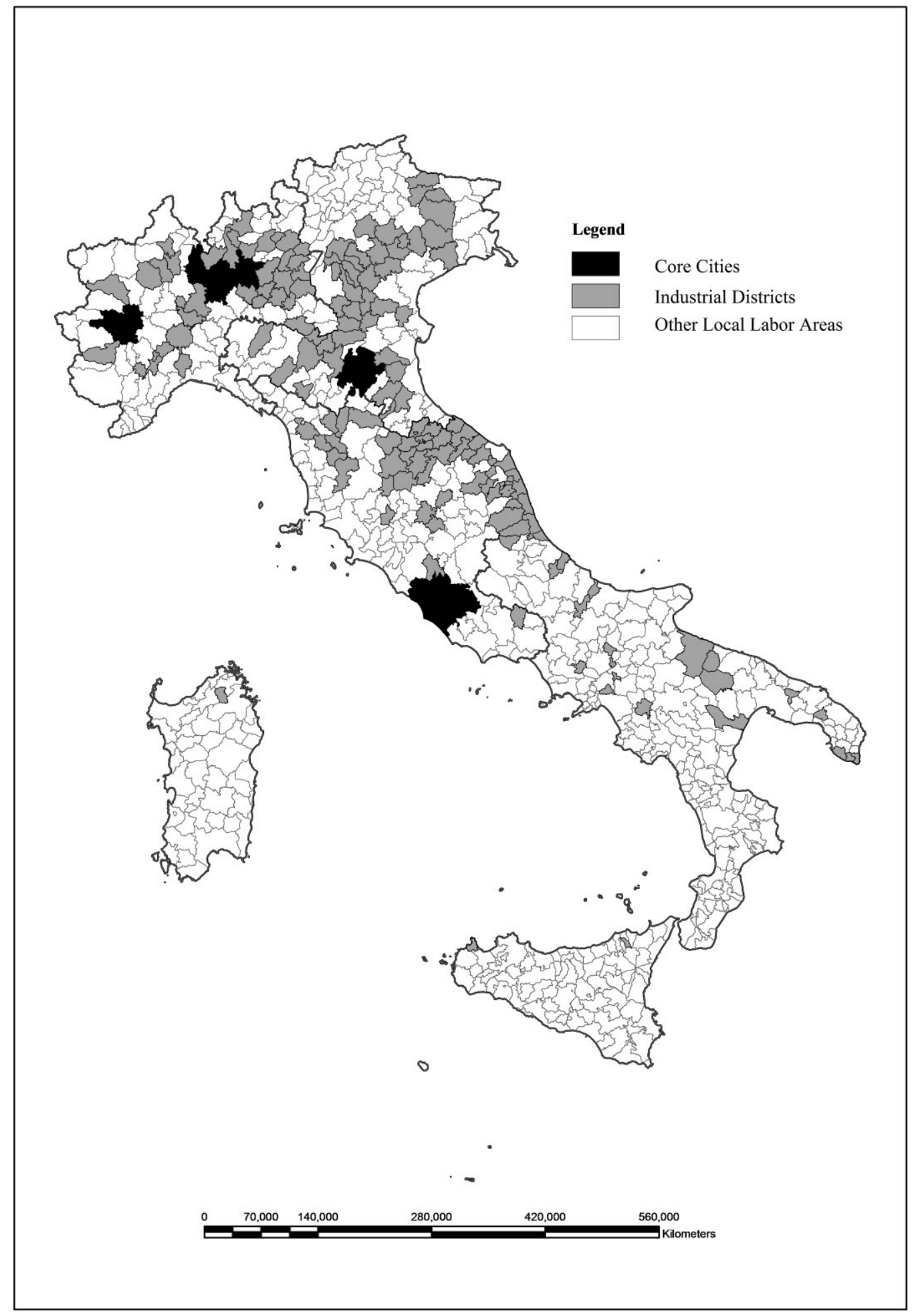

Figure I. The localization of industrial districts and core cities in Italy. 
Table 2

Distribution of Industrial Districts, Core Cities, and Relevant Manufacturing Employees Across Italian Macroregions

\begin{tabular}{|c|c|c|c|c|c|c|c|c|c|c|}
\hline \multirow[b]{3}{*}{ Macroregions' } & \multicolumn{2}{|c|}{ Italy } & \multicolumn{5}{|c|}{ Industrial Districts } & \multicolumn{3}{|c|}{ Core Cities } \\
\hline & \multicolumn{2}{|c|}{ Total Employees } & \multirow[b]{2}{*}{ No. } & \multicolumn{2}{|c|}{$\begin{array}{c}\text { Employees in Specialized } \\
\text { Industries }\end{array}$} & \multicolumn{2}{|c|}{$\begin{array}{c}\text { Employees in } \\
\text { Other Industries } \\
\end{array}$} & \multirow[b]{2}{*}{ No. } & \multicolumn{2}{|c|}{ Employees } \\
\hline & No. & $\%$ & & No. & $\%$ & No. & $\%$ & & No. & $\%$ \\
\hline Northwest & $1,829,123$ & 100 & 39 & 337,351 & 18.4 & 462,069 & 25.3 & 2 & 587,015 & 32.1 \\
\hline Northeast & $1,408,006$ & 100 & 42 & 204,397 & 14.2 & 450,449 & 32.0 & I & 95,565 & 6.8 \\
\hline Center & 870,475 & 100 & 49 & 166,333 & 19.1 & 217,524 & 25.0 & I & 99,351 & 11.4 \\
\hline South and Islands & 798,711 & 100 & 26 & 29,494 & 3.7 & 60,985 & 7.6 & - & - & - \\
\hline Total & $4,906,315$ & 100 & 156 & 737,575 & 15.0 & I,191,027 & 24.3 & 4 & $78 I, 931$ & 15.9 \\
\hline
\end{tabular}

Table 3

Distribution of the 868 Acquisitions Across Four Different Categories and by Type of Ownership

\begin{tabular}{|c|c|c|c|c|c|c|c|c|c|}
\hline \multirow[b]{2}{*}{ Categories } & \multicolumn{3}{|c|}{ Full Acquisitions } & \multicolumn{3}{|c|}{ Partial Acquisitions } & \multicolumn{3}{|c|}{ Total } \\
\hline & No. & $\begin{array}{c}\% \\
\text { (row) }\end{array}$ & $\begin{array}{c}\% \\
\text { (column) }\end{array}$ & No. & $\begin{array}{c}\% \\
\text { (row) }\end{array}$ & $\begin{array}{c}\% \\
\text { (column) }\end{array}$ & No. & $\begin{array}{c}\% \\
\text { (row) }\end{array}$ & $\begin{array}{c}\% \\
\text { (column) }\end{array}$ \\
\hline Districts—specialized industries & 87 & 62.6 & 15.9 & 52 & 37.4 & 16.3 & 139 & 100 & 16.0 \\
\hline Districts - other industries & 115 & 61.2 & 21.0 & 73 & 38.8 & 22.8 & 188 & 100 & 21.7 \\
\hline Core cities & 168 & 67.7 & 30.6 & 80 & 32.3 & 25.0 & 248 & 100 & 28.6 \\
\hline Other areas & 178 & 60.7 & 32.5 & 115 & 39.3 & 35.9 & 293 & 100 & 33.7 \\
\hline Total & 548 & 63.1 & 100.0 & 320 & 36.9 & 100.0 & 868 & 100 & 100.0 \\
\hline
\end{tabular}

Source: Our elaboration.

industries of IDs, CCs, and the remaining areas. In accordance with the aforementioned empirical evidence regarding the location choices of MNEs (Mariotti and Piscitello 1995; McCann and Acs 2011; Rodríguez-Pose and Zademach 2003), CCs account for 28.6 percent of the total deals, a percentage that is nearly twice as large as the share of total manufacturing employees in Italy who work in CCs. However, the two ID categories host acquisitions in a proportion that is similar to the share of employees that fall within each category.

With respect to the distribution of full versus partial acquisitions, the share of full acquisitions hosted by CCs is rather high (68 percent) with respect to the shares hosted by other areas, thus providing some preliminary evidence in favor of our Hypothesis 2 . Conversely, as far as the shares of full acquisitions in both the specialized industries (63 percent) and other industries (61 percent) of IDs, there are only slight differences in acquisition choices compared to acquisition choices in nondistrictual areas. However, such a lack of descriptive evidence for our Hypothesis 1 cannot be regarded as surprising, as the ownership choices of MNEs are likely to be affected by firm- and industry-specific heterogeneity. The need to control for the latter heterogeneities justifies the use of a multivariate econometric analysis. 


\section{Empirical Analysis: Model and Methodology Dependent Variable (Partnership)}

Our dependent variable, Partnership, is a dummy variable that takes a value of 1 for partial acquisitions and a value of 0 otherwise (i.e., for acquisitions that result in 100 percent ownership by the acquiring firm).

\section{Explanatory Variables}

The variable District_specialized is a dummy that takes a value of 1 if the target firm is located in an ID and has a specialization that is the same as the specialized industry of its ID; otherwise, this dummy takes a value of 0 . The variable District_other is a dummy that takes a value of 1 if the target firm is located in an ID but has a different specialization from the ID's specialized industry; otherwise, this dummy takes a value of 0 . In accordance with Hypothesis 1, we expect a negative correlation between District_ specialized and Partnership, while not a significant correlation between District_other and Partnership.

The variable Core_city is a dummy variable that takes a value of 1 if the target firm is located in a CC and a value of 0 otherwise. In accordance with Hypothesis 2, we expect to observe a negative correlation between the Core_city dummy variable and Partnership.

We use the innovation expenditures-to-sales ratio to measure the knowledge intensity for each of the 90 industries in which acquisitions occurred. Innovation expenditures include costs related to intramural and extramural R\&D; the acquisition of external knowledge (the purchase or licensing of patents and nonpatented inventions, expertise, and other types of knowledge from other enterprises or organizations); the acquisition of advanced machinery; industrial design; the marketing and advertising of new products; and personnel training for new products and processes. The data required to calculate this ratio are obtained from the Community Innovation Survey that was performed by ISTAT (2003). These data refer to the expenditures and sales of Italian firms in the year 2000, which is immediately prior to the period that is considered in our study. According to our conceptual framework, we expect a positive correlation between the Knowledge intensity variable and Partnership.

As a proxy for the international excellence of an industry within the host country, we utilized the Revealed Comparative Advantage (RCA) index, which was originally suggested by Balassa (1965). The RCA index is defined as follows:

$$
R C A_{i j}=\left(X_{i j} / \Sigma_{i} X_{i j}\right) /\left(\Sigma_{j} X_{i j} / \Sigma_{i j} X_{i j}\right)
$$

where $X_{i j}$ are exports in sector $i$ from country $j$.

The numerator and denominator represent the share of a given sector $i$ in national exports and world exports, respectively. Thus, the RCA index measures the international performance of sectors as a result of the mix of competitive advantages that exist with respect to the distinctive competences of the country's firms. This index varies around unity; RCA values greater than 1 suggest that an industry is comparatively advantaged relative to other industries, whereas RCA values less than 1 are indicative of a position of comparative disadvantage. The relevant data for the calculation of RCA values come from the Italian National Institute for Foreign Trade for all 90 of the industries that are considered in the present article. These data are used to determine the average RCA value 
for the five years before the year of each observed foreign acquisition in Italy. This approach allows us to control for possible contingent fluctuations in international and national economic trends. ${ }^{9}$ According to our conceptual framework, we expect a positive correlation between the International_competitiveness variable and Partnership.

To classify industries into different life cycle stages, we adopted the approach that was suggested by Audretsch and Feldman (1996), which is based on the idea that the different stages of the industry life cycle can be associated with the type and degree of innovative activity that is occurring in the industry in combination with the type of firm that is generating innovations. To examine product innovation intensity, we use the following criteria: (1) the innovation rate, which is defined as the share of innovative firms (out of the total number of firms) in the industry; and (2) the relative innovative advantage of small firms vis-à-vis large firms. To calculate this innovative advantage, the small-firm innovation rate is defined as the share of innovative small firms $(<250$ employees $)$ out of the total number of small firms in the industry, and the large-firm innovation rate is defined as the share of innovative large firms ( $\geq 250$ employees) out of the total number of large firms in the industry. Consequently, the four stages of the life cycle are defined as follows:

- introduction, if the innovation rate of the industry is in excess of the mean, and small firms have the innovative advantage over large firms;

- growth, if the innovation rate of the industry is in excess of the mean, and large firms have the innovative advantage over small firms;

- maturity, if the innovation rate of the industry is below average, and large firms have the innovative advantage over small firms;

- decline, if the innovation rate of the industry is below average, and small firms have the innovative advantage over large firms.

The data used to quantitatively assess the two aforementioned criteria are obtained from the Community Innovation Survey (ISTAT 2003) and refer to Italian firms that introduced product innovations during the 1998-2000 period. From these data, nine sectors (out of the 90 sectors that are considered in the present article) are in the introduction stage, 29 of the examined sectors are in the growth stage, and 32 and 20 of the examined sectors are in the maturity and decline stages, respectively. Thus, 53 acquisitions (6.1 percent of the total acquisitions) occurred in industries that were in the introduction stage, 424 acquisitions (48.8 percent) occurred in industries that were in the growth stage, 289 acquisitions (33.2 percent) occurred in industries that were in the maturity stage, and 102 acquisitions (11.7 percent) occurred in industries that were in the decline stage.

We constructed four dummies (Introduction, Growth, Maturity, and Decline) that take a value of 1 if an acquisition pertains to a sector in the relevant growth stage and take a value of 0 otherwise. We expect a positive correlation between the Introduction dummy variable and Partnership, but a negative correlation of the latter with each of the other dummy variables.

9 The highest RCA values are evinced by "made in Italy" sectors (homebuilding materials and furniture; leather, textiles and clothing; and machine tools and other machinery), which are the sectors in which Italian firms enjoy international leadership (De Benedictis 2005). In contrast, the lowest RCA values are observed for high-tech sectors (the electronics and electronic instruments, computers, communication equipment, basic chemicals, and aerospace sectors); in these sectors, Italy lags far behind most other advanced countries. 
To account for the previous experience of the MNE in the local context, we use the variable Experience, which measures the number of years that have elapsed since an MNE's first investment in a country (data obtained from the Reprint database). As discussed in the conceptual section, we expect a positive impact of the MNE's previous experience on the dependent variable of this study.

To account for the MNE's nationality, we use the Emerging dummy variable, which takes a value of 1 for firms from countries that were classified as emerging by the World Bank at the beginning of the period that is examined in our analysis; ${ }^{10}$ otherwise, it takes a value of 0 . According with previous literature, we expect to observe a positive relationship between the Emerging dummy variable and the dependent variable.

We constructed the variable Target_size, which is defined as a target firm's number of employees (during the year of an acquisition), and we expect that the likelihood of a partial acquisition will be positively correlated with this variable. Data regarding the size of the target firm are obtained from the Reprint database.

Finally, we control for the year in which acquisitions occurred by adding nine dummy variables (year_t for $\mathrm{t}=2001, \ldots$, 2009; thus, 2010 was used as a benchmark).

\section{The Model}

To test our hypotheses, we employ the following equation model:

$$
\begin{aligned}
\text { Partnership }_{i}= & \beta_{0}+\beta_{1} \text { Spatial_heterogeneity }_{i}+\beta_{2} \text { Industry_heterogeneity }_{i} \\
& +\beta_{3} \text { Firm_heterogeneity }_{i}+\beta_{4} \text { Controls }+\varepsilon_{i}
\end{aligned}
$$

where $i=1,2, \ldots 868$ are the acquisition events; Spatial_heterogeneity refers to both Core_city, District_specialized and District_other; Industry_heterogeneity refers to Knowledge_intensity, International_competitiveness, and the dummy variables that serve as proxies for the stages of the industry life cycle (Introduction, Growth, Maturity, and Decline); Firm_heterogeneity refers to the Parent_experience variable, the Emerging dummy variable and Target_size; Controls refers to temporal dummies; and $\varepsilon$ is the error term.

Given the binary nature of our dependent variable, we employ a probit econometric mode $^{11}$ and assume that observations are independent across continents (i.e., we cluster observations for Asia, Western Europe, Eastern Europe, North America, Latin America and Oceania) but not necessarily within continents; this approach allows for intragroup correlations of standard errors and relaxes the typical requirement that mandates the use of independent observations. ${ }^{12}$

Table 4 provides the descriptive statistics for the dependent and explanatory variables, and Table 5 presents the correlation coefficients among these variables. No multicollinearity problems seem to emerge.

10 In accordance with the World Bank Atlas method of classification, a country was considered to be developing in 2001 if its per capita gross net income was less than US\$9,205.

11 It is worth observing that alternative methodologies could be employed, for example hierarchical models applied both to the dependent variable (see Pan and Tse 2000) and/or the explanatory variables (e.g., Woltman et al. 2012). However, hierarchical models require strong assumptions about the groups and the hierarchies, which need to be confirmed by ensuring a sufficient amount of within- and between-level variance at all the levels of hierarchies. That would transcend the scope of the present article.

12 However, this procedure affects the standard errors and variance-covariance matrix of the estimators (but not the estimated coefficients). 


\section{Table 4}

Descriptive Statistics

\begin{tabular}{lcccc}
\hline & Mean & Standard Deviation & Minimum & Maximum \\
\hline $\begin{array}{l}\text { Dependent variable } \\
\text { Partnership }\end{array}$ & & & & \\
Spatial heterogeneity & 0.631 & 0.482 & 0 & 1 \\
(2) District_specialized & & & & \\
(3) District_other & 0.160 & 0.367 & 0 & 1 \\
(4) Core_city & 0.215 & 0.411 & 0 & 1 \\
Industry heterogeneity & 0.311 & 0.463 & 0 & 1 \\
(5) Knowledge_intensity & & & & \\
(6) International_competitiveness & 0.038 & 0.044 & 0.001 & 0.329 \\
(7) Introduction & 1.689 & 1.127 & 0.04 & 12.022 \\
(8) Growth & 0.061 & 0.239 & 0 & 1 \\
(9) Maturity & 0.488 & 0.500 & 0 & 1 \\
(10) Decline & 0.332 & 0.471 & 0 & 1 \\
Firm heterogeneity & 0.117 & 0.321 & 0 & 19 \\
(II) Experience & & & & 1 \\
(I2) Emerging & 8.490 & 8.177 & 0 & 4740 \\
(13) Target_size & 0.126 & 0.332 & 0 & 1 \\
\hline
\end{tabular}

\section{Results}

Table 6 reports the results from our econometric model. Specifically, Model 1 reports results obtained when inserting only the variables related to the spatial heterogeneity, while in Model 2 industry and firm heterogeneity variables have been added. First, it is notable that the variables that proxy for spatial heterogeneity are highly significant (at $p<0.01)$. In particular, the District_specialized and Core_city variables both negatively affect the likelihood of a partial acquisition, thus confirming that local externalities that relate to both industry-specific agglomeration economies (Hypothesis 1) and variety (Hypothesis 2) may actually substitute for different types of competences that reside in a target firm. Conversely, District_other does not impact an MNE's ownership decision. In other words, the location of the target firm in an ID does not significantly change an MNE's propensity to undertake a partial acquisition if the target and district are differently specialized, thus confirming the industry-specific nature of the fungible externalities among firms within a district (Becattini, Bellandi, and De Propris 2009). It is worth observing that variables related to spatial heterogeneity allow us to correctly classify about 64 percent of observations.

When adding variables that serve as proxies for industry and firm heterogeneities (Model 2), geographic variables maintain their negative sign and significance (both at $p<0.01)$. Additionally, acquisitions that occurred in industries that are more likely to involve postentry learning by the acquirer are also more likely to occur through partial ownership; indeed, both Knowledge_intensity and International_competitiveness do come out positive and significant, at $p<0.10$ and $p<0.05$, respectively. Similarly, in accordance with the industry life cycle theory (Klepper 1997), the likelihood of the partial acquisition of the target company is highest in industries that are in their introduction stage but decreases in subsequent industry cycle stages. Indeed, the coefficient for the Introduction variable is positive and significant (at $p<0.10$ ), whereas the coefficients for Growth and Maturity are negative, although these coefficients are not significantly different from zero. 


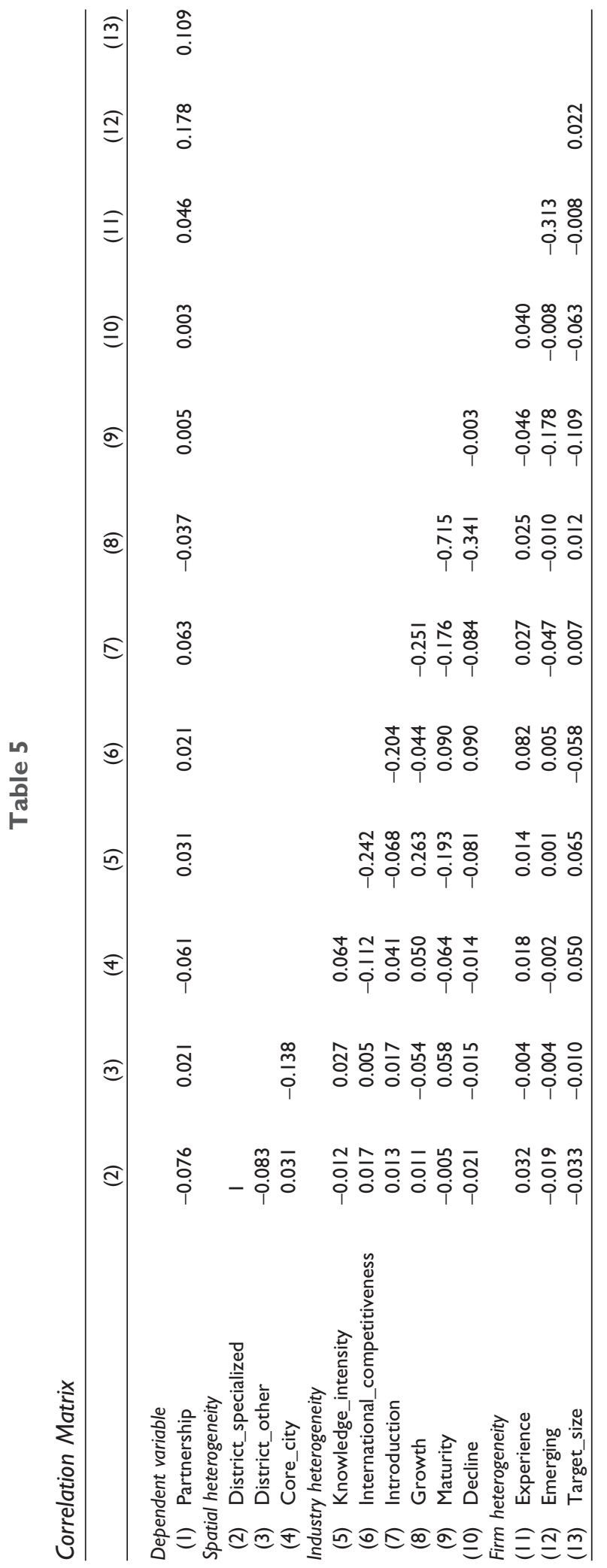


Table 6

Econometric Findings, Probit Models (Dependent Variable $=$ Partnership)

\begin{tabular}{|c|c|c|c|c|c|c|}
\hline \multirow[b]{2}{*}{ Variable } & \multicolumn{3}{|c|}{ Model I } & \multicolumn{3}{|c|}{ Model 2} \\
\hline & Coefficient & $\begin{array}{c}\text { Standard } \\
\text { Error }\end{array}$ & $\begin{array}{c}\text { Marginal } \\
\text { Effect }\end{array}$ & Coefficient & $\begin{array}{c}\text { Standard } \\
\text { Error }\end{array}$ & $\begin{array}{c}\text { Marginal } \\
\text { Effect }\end{array}$ \\
\hline \multicolumn{7}{|l|}{ Spatial heterogeneity } \\
\hline District_specialized & -0.296 & $0.057 * * *$ & -0.106 & -0.273 & $0.059 * * *$ & -0.098 \\
\hline District_other & -0.009 & 0.040 & -0.004 & -0.011 & 0.045 & -0.004 \\
\hline Core_city & -0.174 & $0.047 * * *$ & -0.064 & -0.202 & $0.049 * * *$ & -0.074 \\
\hline \multicolumn{7}{|l|}{ Industry heterogeneity } \\
\hline Knowledge_intensity & & & & 0.049 & $0.024 *$ & 0.018 \\
\hline International_competitiveness & & & & 0.053 & $0.026 * *$ & 0.019 \\
\hline Introduction & & & & 0.469 & $0.262^{*}$ & 0.183 \\
\hline Growth & & & & -0.057 & 0.167 & -0.021 \\
\hline Maturity & & & & -0.011 & 0.171 & -0.004 \\
\hline \multicolumn{7}{|l|}{ Firm heterogeneity } \\
\hline Experience & & & & 0.148 & $0.002 * * *$ & 0.055 \\
\hline Emerging & & & & 0.859 & $0.112 * * *$ & 0.332 \\
\hline Target_size & & & & 0.138 & $0.023 * * *$ & 0.052 \\
\hline Year dummies & yes & & & yes & & \\
\hline No. of observations & 868 & & & 868 & & \\
\hline$\%$ of observations correctly classified & 63.82 & & & 68.97 & & \\
\hline Log pseudolikelihood & -556.09 & & & -510.91 & & \\
\hline
\end{tabular}

Note: Variables have been standardized.

$* p<0.1, * * p<0.05, * * * p<0.01$.

Thus, not only territorial and industrial systems but also relevant differences in industry dynamism and degree of maturity have roles in shaping the interactions between firms and territories (Beugelsdijk 2007; Dicken and Malmberg 2001).

With respect to firm heterogeneity, our estimation confirms that MNEs from emerging countries prefer partial acquisitions that allow them to maintain a local partner (De Beule, Elia and Piscitello forthcoming); in particular, the Emerging variable demonstrates a positive and significant coefficient (at $p<0.01$ ). This preference most likely reflects the phenomenon that these MNEs are using these partial acquisitions to reduce their liabilities of foreignness and origin (Mathews 2006). Similarly, MNEs that are already familiar with the host country are also more likely to maintain a local partner (the estimated coefficient for Experience is positive and significant at $p<0.01)$. Finally, the variable Target_size also possesses a positive and significant coefficient (at $p<0.01$ ); this result confirms the expectations and results of previous empirical research (Hennart and Reddy 1997). Overall, the model predicts our dependent variable rather well, with a success rate of 69 percent.

Because the explanatory variables in these estimations have been standardized, it is possible to compare their coefficients' magnitude and assess the relative weights of the variables that are associated with spatial, industry, and firm heterogeneities. Notably, the country of origin of MNEs has the greatest impact on their attitudes toward partial ownership (the variable Emerging demonstrates the highest coefficient of 0.859); the stage of the industry lifecycle (the coefficient of the variable Introduction is 0.469 ) and local externalities ( -0.273 for District_specialized and -0.202 for Core_city) produce the next largest impacts on these attitudes. The marginal effects that are reported in Table 6 confirm these results. 


\section{Conclusions}

In this article, we have investigated foreign acquisitions that occurred in Italy during the 2001-10 period. In particular, we have analyzed the MNEs' choices with respect to the degree of ownership that they assume in local target firms. Foreign MNEs that wish to access local competences and resources through the acquisition of local target firms often rely on partial acquisitions to reduce the risk of destroying these resources and competences. However, this phenomenon is less frequently observed if target firms are located in areas that are characterized by relevant externalities, such as CCs or IDs. In particular, CCs allow foreign MNEs to access a variety of information, knowledge, and other externalities that are associated with international interconnectedness, whereas IDs provide MNEs with easier access to industry-specific agglomeration economies (a local pool of skilled labor, local input-output linkages, and local knowledge spillovers). Thus, both of these areas reduce an MNE's need to maintain a local partner, although these two types of areas substitute for different aspects of a target firm's competences.

We believe that our results contribute to the literature in several ways. The article adds to economic geography by integrating the literature on local externalities and agglomeration economies with the international business literature on entry modes. ${ }^{13}$ Namely, it develops and empirically tests theory investigating the firm-territory nexus (Dicken and Malmberg 2001), and it provides new insights into how spatial heterogeneity (i.e. the characteristics of local environment and the agglomeration forces) shape the ownership behavior of MNEs in acquiring a foreign firm. The article also adds to the economics and business literature by arguing how the inclusion of spatial heterogeneity into models of entry modes in foreign market can contribute to solve controversial issues between RBV, TCE, and other approaches, which suggest divergent solutions to make effective the acquisition strategy (Chari and Chang 2009). In particular, we suggest that local knowledge externalities can at least partially substitute for competences that are embedded in the target firm, so reducing the need to rely on local partnership, which is otherwise crucial to access country-specific information and competences.

Similar to all other research, our study has certain limitations that provide opportunities for future research. In particular, we are aware that various other dimensions of heterogeneity remain unobservable. This issue is particularly applicable with respect to factors that relate to firms' strategies and structures. Among other considerations, these factors include the specific motivations that underlie an acquisition by an MNE; the type of target firm that is acquired (in terms of organizational structure, in-house knowledge, and various other characteristics); and the degree of complementarity and relatedness between the assets that are controlled by the MNE and the target firm. In addition, we distinguished among various local contexts in terms of the international interconnectedness and industrial variety of these contexts, but these locations also differ with respect to the breadth and depth of their specific portfolio of competencies and knowledge infrastructures; these differences might also impact the attitudes of MNEs toward their subsidiaries. Thus, the consideration of additional facets of heterogeneity is a high priority for our future research because this consideration would allow us to disentangle more readily the effects of the characteristics of the local environment from those of other contingent variables. Although we have striven to examine the

\footnotetext{
${ }^{13}$ Our contribution is in line with the increasing convergence of research interests between international business and geography literature, as it is witnessed by two recent special issues of the Journal of Economic Geography ("International Business and Economic Geography: The Multinational in Geographical Space," 2011), and the Journal of International Business Studies ("The Multinational in Geographic Space," 2013).
} 
intersection of microheterogeneities on the territory, sector, and firm levels, and to join these heterogeneities with models of agglomeration economies, a deeper examination of these heterogeneities will be a crucial aspect of future research in economic geography (Ottaviano 2011). However, we trust that our results can contribute to the ongoing but inconclusive dialogue among geographers, economists, and business analysts that seeks to construct a unified body of theory and a common epistemology (Duranton and Rodríguez-Pose 2005).

\section{References}

Alcácer, J., and Chung, W. 2007. Location strategies and knowledge spillovers. Management Sciences 53:760-76.

Audretsch, D. B., and Feldman, M. P. 1996. Innovative clusters and the industry life cycle. Review of Industrial Organization I I:253-73.

Balakrishnan, S., and Koza, M. 1993. Information asymmetry, adverse selection, and joint ventures: Theory and evidence. Journal of Economic Behavior and Organization 20:99-117.

Balassa, B., 1965. Trade liberalization and revealed comparative advantage. Manchester School of Economic and Social Studies 33:99-123.

Barkema, H. G., and Vermeulen, F. 1998. International expansion through start-up or acquisition: A learning perspective. Academy of Management Journal 47:7-26.

Barney, J. 1991. Firm resources and sustained competitive advantage. Journal of Management 17:99-120.

Bartlett, C. A., and Ghoshal, S. 1989. Managing across borders: The transnational solution. Boston: Harvard Business School Press.

Bathelt, H., Malmberg, A., and Maskell, P. 2004. Clusters and knowledge: Local buzz, global pipelines and the process of knowledge creation. Progress in Human Geography 28:3I-56.

Becattini, G. 1991. The industrial district as a creative milieu. In Industrial change and regional development, ed. G. Benko and M. Dunford, 102-14. London: Belhaven Press.

Becattini, G., Bellandi, M., and De Propris, L. (eds.). 2009. A handbook of industrial districts. Cheltenham, UK: Edward Elgar.

Belussi, F., and Asheim, B. T. 20I0. Industrial districts and globalization. Learning and innovation in local and global production systems. In Business networks in clusters and industrial districts, ed. F. Belussi and A. Sammarra, 246-65. London: Routledge.

Berg, D. B. 200I. Executive retention and acquisition outcomes: A test of opposing views on the influence of organizational tenure. Journal of Management 27:603-22.

Beugelsdijk, S. 2007. The regional environment and a firm's innovative performance: A plea for a multi-level interactionist approach. Economic Geography 83:I8I-99.

Beugelsdijk, S., and Mudambi, R. 20I3. MNEs as border-crossing multi-location enterprises: The role of discontinuities in geographic space. Journal of International Business Studies 44:4I3-26.

Biggiero, L. 2002. The location of multinationals in industrial districts: Knowledge transfer in biomedicals. Journal of Technology Transfer 27: I I I-22.

Boschma, R., and Frenken, K. 20II. The emerging empirics of evolutionary economic geography. Journal of Economic Geography I I:295-307.

Breschi, S., and Lissoni, F. 2009. Mobility of skilled workers and co-invention networks: An anatomy of localized knowledge flows. Journal of Economic Geography 9:439-68.

Brouthers, K. D., and Hennart, J.-F. 2007. Boundaries of the firm: Insights from international entry mode research. Journal of Management 33:395-425.

Cainarca, G. C., Colombo, M. G., and Mariotti, S. 1992. Agreements between firms and the technological life cycle model: Evidence from information technologies. Research Policy 21:45-62. 
Camisón, C. 2004. Shared, competitive, and comparative advantages: A competence-based view of industrial-district competitiveness. Environment and Planning A 36:2227-56.

Cannella, A. A., Jr., and Hambrick, D. C. 1993. Effects of executive departures on the performance of acquired firms. Strategic Management Journal I4:I37-52.

Chari, M. D. R., and Chang, K. 2009. Determinants of the share of equity sought in cross-border acquisitions. Journal of International Business Studies 40:1277-97.

Chen, S.-F., and Hennart, J.-F. 2004. A hostage theory of joint ventures: Why do Japanese investors choose partial over full acquisitions to enter the United States? Journal of Business Research 57: I I26-34.

Combes, P. P., and Duranton, G. 2006. Labour pooling, labour poaching, and spatial clustering. Regional Science and Urban Economics 36:I-28.

Crewe, L. 1996. Material culture: Embedded firms, organizational networks and local economic development of a fashion quarter. Regional Studies 30:257-72.

Dalum, B., Pedersen, C. Ø. R., and Villumsen, G. 2005. Technological life-cycles: Lessons from a cluster facing disruption. European Urban and Regional Studies 12:229-46.

De Benedictis, L. 2005. Three decades of Italian comparative advantages. World Economy 28:1679-709.

De Beule, F., Elia, S., and Piscitello, L. Forthcoming. Entry and access to competences abroad: Emerging market firms vs. advanced market firms. Journal of International Management.

Dicken, P., and Malmberg, A. 200I. Firms in territories: A relational perspectives. Economic Geography 77:345-63.

Drennan, M. P. 1992. Gateway cities: The metropolitan sources of US producer service exports. Urban Studies 29:217-35.

Duranton, G., and Puga, D. 2004. Micro-foundations of urban agglomeration economies. In Handbook of regional and urban economics, ed. J. V. Henderson and J.-F. Thisse, 2063-2II7. Amsterdam: North-Holland.

Duranton, G., and Rodríguez-Pose, A. 2005. When economists and geographers collide, or the tale of the lions and the butterflies. Environment and Planning A 37:1695-705.

Dyer, J., Kale, P., and Singh, H. 2004. When to ally and when to acquire. Harvard Business Review 82:109-15.

Eriksson, R. H. 20I I. Localized spillovers and knowledge flows: How does proximity influence the performance of plants? Economic Geography 87:127-52.

Folta, T. B. 1998. Governance and uncertainty: The tradeoff between administrative control and commitment. Strategic Management Journal 19:1007-28.

Glaeser, E. L., Kallal, H. D., Scheinkman, J. A., and Shleifer, A. 1992. Growth in cities. Journal of Political Economy 100:1 I 26-52.

Goerzen, A., Asmussen, C. G., and Nielsen, B. 2013. Global cities and multinational enterprise location strategy. Journal of International Business Studies 44:427-50.

Harrison, B. 199I. Industrial districts: Old wine in new bottles? Regional Studies 26:469-83.

Haspeslagh, P., and Jemison, D. 199I. Managing acquisitions: Creating value through corporate renewal. New York: Free Press.

Hennart, J.-F., and Reddy, S. 1997. The choice between mergers/acquisitions and joint ventures: The case of Japanese investors in the United States. Strategic Management Journal I8:I-12.

lammarino, S., and McCann, P. 2013. Multinationals and economic geography. Location, technology and innovation. Cheltenham, UK.: Edward Elgar.

ISTAT. 2003. L'innovazione nelle imprese italiane negli anni 1998-2000 [Innovative activities by Italian companies, 1998-2000]. Rome: ISTAT.

—. 2006. Distretti industriali e sistemi locali del lavoro 2001 [Industrial districts and local labour systems, 200I]. Rome: ISTAT.

Jemison, D. B., and Sitkin, S. B. 1986. Corporate acquisitions: A process perspectives. Academy of Management Review II:145-63.

Kim, J., and Mahoney, J. T. 2010. A strategic theory of the firm as a nexus of incomplete contracts: A property rights approach. Journal of Management 36:806-26.

Klepper, S. 1997. Industry life cycles. Industrial and Corporate Change 6:145-82. 
Krug, J. A., and Hegarty, W. H. 1997. Postacquisition turnover among U.S. top management teams: An analysis of the effects of foreign vs. domestic acquisitions of U.S. targets. Strategic Management Journal 18:667-75.

Levitt, B., and March, J. 1988. Organizational learning. Annual Review of Sociology 14:319-40.

Lipsey, R. E., and Sjöholm, F. 2005. Host country impacts of inward FDI: Why such different answers? In Does foreign direct investment promote development? ed. T. H. Moran, E. M. Graham, and M. Blomström, 23-43. Washington DC: Institute for International Economics, Center for Global Development.

Lopéz-Duarte, C., and García-Canal, E. 2004. The choice between joint ventures and acquisitions in foreign direct investments: The role of partial acquisitions and accrued experience. Thunderbird International Business Review 46:39-58.

Lorenzen, M. 2007. Social capital and localized learning: Proximity and place in technological and institutional dynamics. Urban Studies 44:799-8I7.

Lorenzen, M., and Mankhe, V. 2004. Governing MNC entry in regional knowledge clusters. In Knowledge flows, governance and the multinational enterprise, ed. V. Mahnke and T. Pedersen, 2II-25. London: Macmillan.

Madhok, A. 1997. Cost, value, and foreign market entry mode: The transaction and the firm. Strategic Management Journal 18:39-6I.

Maksimovic, V., and Phillips, G. 2008. The industry life cycle, acquisitions and investment: Does firm organization matter? Journal of Finance 63:673-708.

Mariotti, S., and Mutinelli, M. 20I2. Italia multinazionale 2012 [Multinational Italy, 20I2]. Soveria Mannelli, Italy: Rubbettino.

Mariotti, S., and Piscitello, L. 1995. Information costs and location of FDls within the host country: Empirical evidence from Italy. Journal of International Business Studies 26:8I5-4I.

Mariotti, S., Piscitello, L., and Elia S. 2010. Spatial agglomeration of multinational enterprises: The role of information externalities and knowledge spillovers. Journal of Economic Geography 10:519-38.

Markusen, A. 1985. Profits, equilibrium, and regional development. Cambridge, MA: MIT Press.

Marshall, A. 1920. Principles of economics. London: Macmillan.

Mathews, J. A. 2006. Dragon multinationals: New players in 21 th century globalization. Asia Pacific Journal of Management 23:5-27.

McCann, P., and Acs, Z. 20II. Globalization: Countries, cities and multinationals. Regional Studies 45:17-32.

McCann, P., and Mudambi, R. 2005. Analytical differences in the economics of geography: The case of multinational firm. Environment and Planning A 37:1857-76.

Melo, P. C., Graham, D. J., and Noland, R. B. 2009. A meta-analysis of estimates of urban agglomeration economies. Regional Science and Urban Economics 39:332-42.

Meyer, K. E., Wright, M., and Pruthi, S. 2009. Managing knowledge in foreign entry strategies: A resource-based analysis. Strategic Management Journal 30:557-74.

Moodysson, J. 2008. Principles and practices of knowledge creation: On the organization of "buzz" and "pipelines" in life science communities. Economic Geography 84:449-69.

Neffke, F., Henning, M., Boschma, R., Lundquist, K.-J., and Olander, L.-O. 20I I. The dynamics of agglomeration externalities along the life cycle of industries. Regional Studies 45:49-65.

Nielsen, B. B., and Nielsen, S. 20I I. The role of top management team international orientation in international strategic decision-making: The choice of foreign entry mode. Journal of World Business 46:185-93.

North, D. 1990. Institutions, institutional change, and economic performance. Cambridge: Cambridge University Press.

Organization for Economic Cooperation and Development. 2002. Redefining territories. The functional regions. Paris: Organization for Economic Cooperation and Development.

Ottaviano, G. I. P. 20II. "New" new economic geography: Firm heterogeneity and agglomeration economies. Journal of Economic Geography 29:23 I-40.

Pan, Y., and Tse, D. K. 2000. The hierarchical model of market entry modes. Journal of International Business Studies 31:535-54. 
Pentoniemi, M. 20II. Reviewing industry life-cycle theory: Avenues for future research. International Journal of Management Reviews 13:349-75.

Phene, A., Tallman, S., and Almeida, P. 2012. When do acquisitions facilitate technological exploration and exploitation? Journal of Management 38:753-83.

Potter, A., and Watts, H. D. 20II. Evolutionary agglomeration theory: Increasing returns, diminishing returns, and the industry life cycle. Journal of Economic Geography I I:417-55.

Power, D., and Lundmark, M. 2004. Working through knowledge pools: Labour market dynamics, the transference of knowledge and ideas, and industrial clusters. Urban Studies 4I:102544.

Rajan, R. G., and Zingales, L. 1998. Power in a theory of the firm. Quarterly Journal of Economics II 3:387-432.

Ramachandran, J., and Pant, A. 2010. The liabilities of origin: An emerging economy perspective on the costs of doing business abroad. In The past, present and future of international business \& management, ed. T. Devinney, T. Pedersen, and L. Tihanyi, 23I-65. Bingley, UK: Emerald Group Publishing.

Ramamurti, R. 2009. What have we learned about emerging-market MNEs? In Emerging multinational from emerging markets, ed. R. Ramamurti, and J. V. Sing, 399-426. Cambridge: Cambridge University Press.

Rodríguez-Pose, A., and Zademach, H.-M. 2003. Rising metropoli: The geography of mergers and acquisitions in Germany. Urban Studies 40:1895-923.

- 2006. Industry dynamics in the German merger and acquisitions market. Tijdschrift voor Economische en Sociale Geografie 97:296-313.

Sassen, S. 2009. Cities today: A new frontier for major developments. Annals of the American Academy 626:53-7I.

Short, J. R., Breitbach, C., Buckman, S., and Essex, J. 2000. From world cities to gateway cities: Extending the boundaries of globalization theory. City 4:317-40.

Sitkin, S. 1992. Learning through failure: The strategy of small losses. In Research in organizational behavior, ed. B. Staw and L. Cummings, 23I-66. Greenwich, CT: JAI Press.

Storper, M., and Venables, A. J. 2006. Buzz: Face-to-face contact and the urban economy. In Clusters, networks and innovation, ed. S. Breschi and F. Malerba, 319-42. Oxford: Oxford University Press.

Taylor, P. J. 200I. Specification of the world city network. Geographical Analysis 33:18I-94.

- 2004. World city network: A global urban analysis. London: Routledge.

- 2005. Global network service connectivities for 315 cities in 2000. Data Set 12 of the Globalization and World Cities Research Network. Available online: http://www.lboro.ac.uk/ gawcl.

Trippl, M., Todtling, F., and Lengauer, L. 2009. Knowledge sourcing beyond buzz and pipelines: Evidence from the Vienna software sector. Economic Geography 85:443-62.

Tse, D. K., Pan, Y., and Au, K. Y. 1997. How MNCs choose entry modes and form alliances: The China experience. Journal of International Business Studies 28:779-805.

United Nations Conference on Trade and Development. 20II. World investment report 20II. New York and Geneva: United Nations.

Wells, L. T. 1983. Third world multinationals: The rise of foreign investment from developing countries. Cambridge, MA: MIT Press.

Whited, T. 2006. External finance constraints and the intertemporal pattern of intermittent investment. Journal of Financial Economics 81:467-502.

Williamson, O. E. 1985. The economic institutions of capitalism: Firms, markets, relational contracting. New York: Free Press.

Woltman, H., Feldstain, A., Mackay, J. C., and Rocchi, M. 2012. An introduction to hierarchical linear modeling. Tutorials in Quantitative Methods for Psychology 8:52-69.

Yin, X., and Shanley, M. 2008. Industry determinants of the "merger versus alliance" decision. Academy of Management Review 33:473-91.

Zaheer, S. 1995. Overcoming the liability of foreigness. Academy of Management Journal 38:34I63. 


\section{Appendix 1: Industrial Districts (IDs)}

To identify the IDs among the 686 Local Labor Areas (LLAs), ISTAT (2006) developed a Cluster Mapping Project that utilized the four criteria described in the following paragraphs.

If total employment is indicated by $E$, LLAs are denoted by the subscript $j$, each manufacturing sector is represented by the subscript $i$, and the entire manufacturing industry is indicated by $m$, a specific LLA is identified as ID if it fulfills the following four conditions:

$$
\left(E_{j m} / E_{j}\right) /\left(E_{m} / E\right)>1
$$

which states that the share of the manufacturing employment on the total employment must be higher in the area in question than at the national level.

$$
\left(E_{j m, \text { small }} / E_{j m}\right) /\left(E_{m, \text { small }} / E_{m}\right)>1
$$

where the subscript small indicates employment in firms with less than 100 employees. Thus, this condition specifies that the share of the employment in small and medium enterprises on the manufacturing employment must be higher in the area in question than at the national level.

$$
\left(E_{j i} / E_{j m}\right) /\left(E_{i} / E_{m}\right)>1
$$

which requires that for at least one sector, the specialization index of the area, that is, the ratio between the share of the sector employment on the manufacturing employment in the area and the corresponding share at the national level, must be greater than one.

$$
\left(E_{j i, \text { small }} / E_{j i}\right) /\left(E_{i, \text { small }} / E_{i}\right)>1
$$

which states that in at least one sector for which the specialization index of the area is greater than one, the share of the employment in small and medium enterprises on the sector employment must be higher in the area than at the national level.

Using these conditions, ISTAT identified 156 LLAs as IDs.

\section{Appendix 2: Core Cities (CCs)}

CCs are identified from Taylor's database, in which international leading cities are classified and ranked by their degree of connectivity to the world city network in the year 2000 (see Taylor 2001 for the methodology of this approach and Taylor 2005 for the relevant data). Only four out of the nine Italian cities that were included on the list possessed degrees of connectivity above the first quartile of the distribution of the leading cities that were examined. In particular, these four cities were Milan, Rome, Turin, and Bologna. Unsurprisingly, the Local Labor Areas (LLAs) that included these 
four cities also ranked as the Italian areas that hosted the highest shares of manufacturing and service affiliates of multinational enterprises (MNEs) (see Table A1).

By a large margin, Milan is the Italian city that is the most connected to the world city network; Milan also includes the lion's share of the total affiliates of foreign MNEs that exist in Italy. In fact, in addition to the specific LLA of Milan itself, the metropolitan area surrounding this city includes at least four other LLAs that are highly interconnected adjoining territories (namely, Bergamo, Busto Arsizio, Seregno, and Varese; see Figure 1 in the main text of this article). These LLAs constitute the industrial belt of the city; the two main international airports that serve the metropolis of Milan (Malpensa and Orio al Serio) are also located in this industrial belt.

In summary, we consider the eight LLAs that surround the aforementioned four cities to be CCs.

\section{Table Al}

Core Cities in Italy, 2000

\begin{tabular}{lcccc}
\hline City & $\begin{array}{c}\text { Connectivity } \\
\text { Index }\end{array}$ & $\begin{array}{c}\text { World City Network } \\
\text { Worldwide Ranking }\end{array}$ & $\begin{array}{c}\text { Share of MNE Affiliates } \\
\text { (\% of total in Italy) }\end{array}$ & $\begin{array}{c}\text { Italian Rank in Terms of } \\
\text { MNE Affiliates }\end{array}$ \\
\hline Milan & 60.4 & 8 & 20.5 & 1 \\
Rome & 36.3 & 53 & 7.8 & 2 \\
Turin & 13.1 & 192 & 6.3 & 3 \\
Bologna & II.I & 213 & 2.8 & 4 \\
\hline
\end{tabular}

I Maximum value $=100$.

Source: Our elaboration of results from Taylor (2005) and Mariotti and Mutinelli (2012). 